\title{
KEBIJAKAN RAMAH PEREMPUAN DAN ANAK DALAM MERESPON ANTAGONISME INDUSTRI RAMBUT DAN BULU MATA PALSU DI KABUPATEN PURBALINGGA
}

\author{
Tobirin, Muhadjir Darwin, Ambar Widaningrum \\ Universitas Jenderal Soedirman Purwokerto, Universitas Gadjah Mada \\ Yogyakarta \\ tobi.rifan@gmail.com, muhadjir.darwin@gmail.com, ambarwid@ugm.ac.id
}

\begin{abstract}
ABSTRAK
Artikel ini mendiskusikan keberadaan industri rambut dan bulu mata palsu yang memberikan kemudahan aksesibilitas bagi perempuan untuk bekerja dan menghasilkan upah yang layak. Melalui kerja yang dibayar perempuan menjadi mandiri, dan memiliki status sosial yang meningkat. Namun masalah muncul pada saat perempuan bekerja, masalah tersebut berkaitan dengan pengasuhan dan pendidikan anak, beban ganda, disharmonisasi keluarga dan tingkat gugat cerai yang tinggi.Tujuan penulisan artikel ini menganalisis dampak industrialisasi dan respon negara dalam kebijakan ramah perempuan dan anak.Penelitian ini menggunakan metode mixed methode dengan subyek penelitian buruh perempuandan keluarga, pelaku industri, aparat pemerintah daerah dan tokoh masyarakat. Hasil penelitian menunjukkan perempuan buruh memiliki peran baru sebagai pencari nafkah utama danmandirisecara ekonomi, peningkatan partisipasi kerja perempuan dan tata nilai baru dalam masyarakat yang menganggap perempuan lebih dominan dibandingkan laki-laki, kebijakan ramah perempuan belum menyentuh persoalan sebenarnya dalam mewujudkan keadilan dan kesetaraan gender.
\end{abstract}

Kata Kunci: industrialisasi, kebijakan ramah perempuan, respon Negara 


\section{ABSTRACT}

This article discusses the existence of wig and fake eyelash industries that provide easy accessibility for women to work and generate decent wages. In one hand, women become independent, and have increased social status. But in another hand, problems arise when women work, especially those related to child care and education, double burden, family disharmony and high divorce rate. This article aims to analyze the impact of industrialization and the state's response to the friendly policies of women and children. This study uses a mixed method with research subjects of women and family workers, entrepeneurs, local government officials and community leaders. The results of the study show that women workers have a new role as the main breadwinner and are economically independent. In addition, there is an increase in the participation of women and new values in the community who consider women more dominant than men. However, women's friendly policies have not touched the real problem in realizing gender justice and equality.

Keywords: industrialization, women's friendly policy, country response

\section{A. Pendahuluan}

Kebijakan ramah perempuan menjadi penting dalam dunia kerja, di saat perempuan dan dunia kerja masih mengalami ketidaksetaraan gender di pasar kerja.Partisipasi angkatan kerja perempuan yang rendah, berkisar antara 48-52 persen selama lima tahun terakhir,prosentasi partisipasi angkatan kerja perempuan masih jauh lebih rendah dibandingkan laki-laki, dengan tingkat partisipasi angkatan kerja perempuan tahun 2015 sebesar 48,87 sementara tingkat partisipasi angkatan kerja laki-laki sebesar 82,71 (Said, et al, 2016: 21). Tingkat partisipasi angkatan kerja yang masih rendah dari perempuan tersebut, diperlukan political will dari pemerintah secara struktural untuk mewujudkan kontruksi sosial di pasar kerja dengan semangat humanis, tidak tersegementasi dan memihak pada perempuan. Pasar tenaga kerja tidak mengalami hambatan struktural, tetapi didasarkan pada segmen yang kompetitif atas dasar sumber daya dan keahlian (Effendi, 2013: 7-9). Mengingat hal demikian, negara, pemerintah, pelaku industri dan stakeholder lainnya seharusnya mampu melakukan perlindungan pada buruh perempuan, 
sudah menyentuh dalam level substantive bukan level UU bahkah protektif, bentuk perlindungan substantive dengan melakukan penghapusan hambatan hukum terhadap kesetaraan perempuan dalam pasar tenagakerja, mengambil tindakan afirmatif untuk mengatasi dampak diskriminasi di masa lalu dan mempromosikan kesempatan dan perlakuan yang adil di pasar tenagakerja (Apriando, 2013: 10-13).

Respons negara melalui agenda kebijakan ramah perempuan dan keterbukaan pasar kerja memberikan jalan bagi perempuan memasuki dunia kerja dengan keunggulan kompetitif. Perempuan yang bekerja memperoleh penghasilan, memiliki kemampuan ekonomi, mengusai asset keluarga dan memiliki posisi tawar dengan suami. Pandangan Poire (2006: 70) terjadi pola complementary role relasi suami-istri berperan secara jelas dalam peran nurtureryaitu secara kontruksi sosial peran laki-laki dan perempuan saling melengkapi sesuai dengan tugas dan tanggungjawabnya secara budaya, lakilaki sebagai penyedia atau provider pencari nafkah,memasok biaya-biaya untuk pengobatan, terapi, pakaian, makanan sedangkan istri berperan domestik, kondisi ini bisa saja berubah sesuai dengan perubahan dan transformasi sosial dalam keluarga tersebut. Studi dan pendapat yang sama dari (Rofi'ah, 2015: 93107) Konstruksi pola relasi gender yang berkeadilan dan berkesetaraangender akan terwujud, apabila ada kerjasama dalam pembagian peran yang setara dan adil antarasuami dan istri, dan merujuk pada perencanaan, pelaksanaan manajemen sumberdayakeluarga, sehingga anggota keluarga mempunyai pembagian peran dalam berbagai aktivitasdomestik dan publik.

Selain itu, ada perubahan yang menggembirakan dari kesadaran institusi publik, kebijakan publik pada dua dekade terakhir telah terlihat pergeseran pendekatan negara, di mana perempuan menjadi prioritas, posisi dan identitas perempuan menjadi fokus utama dari kebijakan dan program negara.Negara sejak paska reformasi memiliki komitmen dalam peningkatan hadirnya negara untuk kebijakan ramah perempuan.Reformasi memberikan ruang dan membuka kesempatan yang luas bagi keterlibatan perempuan, dalam ruang politik, sosial budaya dan pengambilan kebijakan.

Kebijakan ramah perempuan yang dihasilkan pasca reformasi adalah sebagai berikut; 
Tabel 1. Produk Kebijakan Publik Ramah Perempuan Pasca Reformasi Sumber: Dhewy (2017:5).

\begin{tabular}{|c|c|c|}
\hline No & Produk Undang-Undang/Regulasi & Mengatur Perihal \\
\hline 1 & Inpres No. 9 Tahun 2000 & $\begin{array}{l}\text { Tentang Pengarusutamaan Gender } \\
\text { Dalam Pembangunan Nasional }\end{array}$ \\
\hline 2 & Kepmendagri No. 132 Tahun 2003 & $\begin{array}{l}\text { Tentang Pedoman Pelaksanaan PUG } \\
\text { Dalam Pembangunan di Daerah }\end{array}$ \\
\hline 3 & Kepmendagri No 15 Tahun 2008 & $\begin{array}{l}\text { Pengganti Kepmendagri No } 132 \text { Ta- } \\
\text { hun } 2003 \text { Tentang Tentang Pedoman } \\
\text { Pelaksanaan PUG Dalam Pembangu- } \\
\text { nan di Daerah }\end{array}$ \\
\hline 4 & UU No 23 tahun 2004 & $\begin{array}{l}\text { tentang penghapusan kekerasan da- } \\
\text { lam rumah tangga, }\end{array}$ \\
\hline 5 & UU No 12 tahun 2006 & tentang kewarganegaraan \\
\hline 6 & UU No 21 tahun 2007 & $\begin{array}{l}\text { tentang pemberantasan tindak perda- } \\
\text { gangan Orang }\end{array}$ \\
\hline 7 & UU No. 36 tahun 2009 & tentang kesehatan \\
\hline 8 & UU No 52 Tahun 2009 & $\begin{array}{l}\text { Tentang perkembangan Kependudu- } \\
\text { kan dan Pembangunan Keluarga }\end{array}$ \\
\hline 9 & UU No 15Tahun 2011 & Tentang penyelenggara Pemilu \\
\hline 10 & UU No. 10 tahun 2012 & tentang Pemilu \\
\hline 11 & UU No 7 Tahun 2012 & Tentang penanganan konflik Sosial \\
\hline
\end{tabular}

Proses transformasi peran negara semakin menunjukkan kebeperpihakan pada perempuan dengan kebijakan ramah perempuan dan anak yang semakin menunjukkan sisi positifnya.Salah satunya adalah perhatian negara dalam hal ini pemerintah daerah Kabupaten Purbalingga yang melakukan berbagai kebijakan pembangunan yang berpihak pada pemerataan sekaligus berbasis pada keadilan gender. Keberadaan industri rambut dan bulu mata palsu sebagai bentuk perhatian untuk meningkatkan peran gender perempuan, memiliki kemudahan aksesibilitas dalam mendapatkan pekerjaan dan mandiri secara ekonomi.Kondisi ini menyebakan peran gender perempuan semakin meningkat di ranah publik yang secara langsung berpengaruh pula terhadap peran domestik, dimana pembagian kerja pada rumah tangga keluarga buruh industri, perempuan memiliki otoritas dan pola pembagian kerja tidak lagi berdasarkan pada pola lama yang menempatkan perempuan sebagai pekerja domestik dan laki-laki dalam ranah publik. 
Perubahan peran gender perempuan tersebut sebagai dampak keberadaan industri rambut dan bulu mata palsu, dimana perempuan memiliki kesempatan yang lebih terbuka dibanding dengan laki-laki. Hal ini dipertegas dengan data tahun 2016 menunjukkan adanya 48 perusahaan pengolahan rambut yang menyerap 32.386 orang pekerja di mana 83 persennya 21 (27.032 orang) adalah pekerja perempuan di mana sembilan orang diantaranya adalah pekerja Warga Negara Asing (WNA). Adapun pekerja laki-laki hanya sebesar 17 persen (5.354 orang) di mana 58 orang di antaranya adalah WNA (Disnaker Kabupaten Purbalingga, 2016)

Dinamika peran baru perempuan dihadapkan pada perspektif yang berbeda antara buruh dan keluarga buruh, masyarakat dan negara. Buruh perempuan menganggap peran publik yang dijalankan adalah wujud aktualisasi dan kesempatan yang terbuka untuk mendapatkan upah yang diharapkan dalam menjamin keberlangsungan keluarga, masyarakat menganggap keberadaan industri rambut dan bulu mata palsu menimbulkan kesenjangan kesempatan kerja dan lebih memperhatikan perempuan yang berakibat pada perempuan yang lebih dominan. Sisi lain negara belum hadir dalam menanggapi, mensikapi permasalahan dan kebutuhan buruh perempuan akibat perubahan dan pergeseran peran publik perempuan.

Berawal dari kerangka pikir tersebut, penelitian ini memfokuskan dan mengkaji tentang peran baru perempuan dan kebijakan ramah perempuan dalam merespon dampak industrialisasi rambut dan bulu mata palsu di Kabupaten Purbalingga.Berbagai permasalahan dan kontradiksi muncul dalam masyarakat industri baru, buruh perempuan ditingkat domestik dianggap mendominasi laki-laki, sementara ditingkat publik sebagai buruh perempuan masih dihadapkan pada situasi yang tidak menguntungkan.Buruh perempuan masih mengalami diskriminasi, subordinasi dan terabaikannya hak-hak reproduksinya.

Ditingkat domestik belum adanya kesadaran gender yang baik pada akhirnya menimbulkan permasalahan baru tentang pembagian perannya dalam mengasuh anak, mendampingi dan mendidik anak, layanan penitipan anak dan kebutuhan tumbuhkembang anak. Hal ini ditunjukkan dengan banyaknya kasus kekerasan terhadap anak yang terus meningkat seiring 
dengan tidak adanya kepedulian terhadap nasib anak. Tercatat pada tahun 2016 terdapat kasus kekerasan ada 39 dengan 29 di antaranya menimpa anak-anak (Harian Radar Banyumas, Kamis 17 November 2016). Selain itu kekerasan dalam rumah tangga (KDRT) yang terjadi pada perempuan dan anak semakin tinggi,gugat cerai yang terus meningkat setiap tahunnya. Kompleksitas masalah inilah yang akan dikaji dari sudut pandang kebijakan ramah perempuan dan anak sebagai proses antisipasi dampak industrialisasi. Bagaimana negara atau pemerintah daerah merespon permasalahan dampak industri rambut dan bulu mata palsu? Perubahan seperti apa dalam proses rekontruksi gender serta tatanilai baru yang berkembang di masyarakat industri baru?

Kajian ini tidak lepas dari landasan teoritik pandangan teori post stukturalis dalam memahami pergeseran peran gender perempuan dari domestik ke publik. Perempuan dalam domain privat tidak lebih dari korban sistematik kekuasaan, modal dan modernitas.Perempuan menjadi wacana yang setiap saat teralienasi oleh modernitas dengan simbol pembangunan dan pertumbuhan.Modernisasi menjadi ciri terperangkapnya ruang publik yang lebih memungkinkan orang pada ketidakberdayaan, irasionalitas dan mengalami dehumanisasi.Perempuan mengalami simbolisasi korban dari pembangunan yang termarginalkan dan mengalami kekerasan. Domain privat yang diperankan perempuan berlangsung dalam proses panjang sebagai ketidakberdayaan terhadap dominasi laki-laki di ruang publik (Aziz, 2007:99).

Perempuan dan ranah domestik berawal dari pembagian kerja secara seksual dan dianggap secara alamiah, laki-laki pergi untuk berperang, berburu, sebagai bagian dari kategori sedangkan perempuan bekerja seperti ada dalam dirinya sendiri, yaitu memasak, membersihkan dan mengasuh anak.Perempuan dihadapkan pada kesulitan untuk mengakses kehidupan bermasyarakat, menempatkan fungsinya dalam ranah domestik, ketergantungan terhadap laki-laki mulai besar, dan pada akhirnya laki-laki secara dominan menguasai ranah publik.Menurut Budiman (2006:145) ruang domestik perempuan didefinisikan menurut fungsinya, yaitu ruang untuk istirahat, untuk duduk, untuk tidur, untuk makan, untuk bersih- 
bersih.Asumsinya ruang domestik diporsikan sebagai wilayah perempuan, sedangkan ruang tamu diasumsikan sebagai ruang laki-laki untuk menerima tamu.

Asumsi publik dan privat tidak dapat dipisahkan dari konsep keluarga yang memiliki peran secara struktur dan fungsional.Pandangan liberal tradisional menganggap keluarga sebagai pusat kehidupan privat. Keluarga unit yang secara biologis menunjuk pada peran laki-laki pada wilayah publik, laki-laki dewasa berhubungan dengan laki-laki dewasa lain sesuai dengan konvensi yang telah disepakati, dan pihak lain adalah privat yang diatur secara simpati dan alamiah. Perempuan menjalankan pekerjaan yang dipimpin oleh laki-laki di ranah domestik tanpa upah (Kymlicka, 2004:329-332).

Sejarah kapitalisme menghasilkan kelas menengah baru dengan identitas yang berbeda dari orang kaya dan orang miskin.Kelas menengah mengatur urusan privat dan publik menjadi urusan yang dipisahkan.Masalah privat terpisah dariurusan, pasar, pemerintahan, dan urusan negara.Kelompok kelas menengah menolak ranah domestik sebagai sifat yang dikaitkan dengan sisi emosi dan perempuan.Kontruksi yang dibangun tentang publik adalah dengan modal budaya, lingkungan ekonomi dan politik.Keluarga adalah masalah privat yang diasumsikan pria sebagai wakil publik yang mengurus transaksi rumah tangga properti, politik dan masalah publik lainnya, sementara wanita mempertahankan rumah secara pribadi.Perempuan tidak dapat lepas dari ruang privat tidak dapat terhindar dari lingkaran pekerjaan rumah tangga (Talbot, 2011:208).

Milnor (2005:360) dalam bukunya yang berjudul Gender, Domesticity, and the Age ofAugustus: Inventing Private Life,mengajak pembaca untuk mengubah perhatian bahwa rumah tangga sebagai salah satu alat yang kuat untuk mengubah pandangan perempuan berfungsi secara fugsional dalam ruang domestik tetapi dalam rumah tangga dapat menyebabkan penggunaan sebagai peran publik karena mewakili negara. Rumah tangga sebagai cara untukberbicara tentang politik dan sejarah, peran rumah sebagai simbol publik sebagai representatif ada perbedaan budaya dan keunggulan tempat di mana kekuasaan dapat ditampilkan melalui kemenangan arsitekturpengetahuan atas keinginan untuk privasi dalam deskripsi rumah. Milnor menganalisis 
penguatan, ideologi feminitas pada periode Augustan, undang-undang Augustan membuat wanita untuk pertama kalinya bertanggung jawab untuk mereka sendiri tindakan di depan negara, memperoleh semacam subjektivitas hukum.

Metode dalam penelitian ini mixed method, pengumpulan data kuantitatif dengan menggunakan metode survey untuk mengetahui sikap, perilaku, otoritas kekuasaan dalam keluarga buruh perempuan. Sebagai sebuah metoda, mixed methods research berfokus pada pengumpulan dan analisis data serta memadukan antara data kuantitatif dan data kualitatif baik dalam single study maupun series study. Premis sentral yang dijadikan dasar mixed methods research adalah menggunakan kombinasi pendekatan kuantitatif dan kualitatif untuk menemukan hasil penelitian yang lebih baik dibandingkan jika hanya menggunakan salah satu pendekatan saja (Byrne \& Aine M.Humble, 2007).

Sesuai dengan latar belakang, kajian teoritik dan metode yang digunakan penelitian ini mengacu pada penelitian sebelumnya yang menyebutkan bahwa angkatan kerja laki-laki yang terserap di sektor pengolahan rambut sekitar 20\% dari tenaga kerja perempuan. Terjadinya ketimpangan dalam penyerapan tenaga kerja oleh karena itu pemerintah Kabupaten Purbalingga merumuskan kebijakan pembangunan yang berpihak pada pemerataan terutama kesempatan yang sama dalam pekerjaan antara laki-laki dan perempuan (Setiansah dan Shinta Prastyanti, 2011: 37-45). Selain itu penelitian dari Puspita, Rin Rostikawati dan Lilis, (SS, 2014: 420-429) yang menyebutkan peralihan peran gender dimana perempuan lebih terbuka mendapatkan kesempatan kerja dibandingkan laki-laki pada industri rambut palsu di Kabupaten Purbalingga menyebabkan program penyuluhan Keluarga Berencana (KB) harus menyasar laki-laki sebagai strategi utama dalam pengendalian penduduk. Faktor keberhasilan program KB adalah dengan pendekatan yang holistik terutama pada laki-laki suami buruh keterlibatan laki-laki menjadi penting. Posisi artikel ini sesuai dengan kajian yang telah dilakukan sebelumnya adalah menekankan pada analisis dan penjelasan implikasi dari peran baru perempuan dan kemandirian ekonomi perempuan pada ranah domestik dan respon negara dalam merumuskan kebijakan family 
care yang sesuai dengan kebutuhan dan dinamika perubahan peran gender perempuan.

\section{B. Pembahasan}

\section{Peran baru Perempuan dan kontruksi gender Dalam Dinamika}

\section{Keluarga Buruh}

Industrialisasi dan pertumbuhan ekonomi perlahan telah mengurangi masalah yang dihadapi perempuan pada masyarakat miskin, terutama bagaimana mengatasi kesehatan dan kematian bayi, keaksaraan dan sekolah, upah subsisten, diskriminasi dan kesenjangan gender. Pernyataan tersebut merupakan hipotesis dalam buku Rising Tide Gender Equality and Cultural Change around the World yang menegaskan bahwa teori modernisasi yang telah direvisi dan dikembangkan menyatakan perkembangan manusia membawa perubahan pada sikap budaya menuju kesetaraan gender di hampir semua masyarakat yang mengalami berbagai bentuk modernisasi yang ditandai dengan pembangunan ekonomi yang lebih cepat. Modernisasi membawa perubahan yang sistematis dan dapat diprediksi dalam peran gender. Dampak modernisasi tersebut diidentikkan dengan fase berikut:1) Fase industrialisasi yang membawa perempuan ke dalam tenaga kerja yang dibayar, perempuanberpeluang dalam pendidikan yang lebih besar. Perempuan diberi hak pilih, dan mulai berpartisipasi dalam pemerintahan atau politik. 2) Fase postindustri membawa pergeseran menuju gender dengan tingkat kesetaraan yang meningkat, perempuan mengalami peningkatan dalam manajemen dan profesi, memiliki pengaruh politik dan pengambilan keputusan, di masyarakat ada dorongan sikap yang lebih egaliter terhadap perempuan (Inglehart \& Pippa Norris, 2003: 10-11).

Sementara itu perubahan peran gender perempuan pada tingkatan praktis terlihat pada perempuan yang dipekerjakan sebagai angkatan kerja formal semakin meningkat. Perempuan dibayar sesuai dengan profesionalisme sebagai pekerja, otomatis akanmendorongpeningkatan pendapatan bagi perempuan. Posisi perempuan sebagai pekerja subsisten dengan bayaran yang rendah berganti posisi dengan lebih banyak ditempatkan sebagai tenaga kerjayang lebih bersifat manajerial dan pengambil keputusan. Perempuan 
berkembang pesat dan mengalami kemajuan dalam bidang kesehatan, memiliki kemampuan ekonomi dan mampu mengakhiri diskiriminasi gender pada perusahan besar di mana tempat perempuan bekerja. Selain itu perempuan tidak lagi diidentikkan dengan peran domestik yang hanya berperan mengurus keluarga dan menjalankan peran yang dianggap tidak berkontribusi terhadap peran-peran produktif (Chu \& Charles Posner, 2013: 1)

Perubahan peran gender ini berlaku global termasuk di Indonesia, sesuai dalam buku gender tahun 2016 disebutkan bahwa pembangunan gender di Indonesia telah mencapai perkembangan gender yang menggembirakan di tengah permasalahan perempuan yang masih perlu mendapat perhatian. Perkembangan gender digambarkan dengan hal berikut;

1. Profesionalisme Perempuan dalam Dunia Kerja Semakin diperhitungkan, perempuan tidak hanya sebagai pekerja formal tetapi ditingkat pimpinan atau manajer mampu bersaing dengan laki-laki, perempuan memiliki posisi strategis dalam menduduki jabatan di pemerintahan, perusahaan maupun organisasi sosial lainya. Perempuan dihargai bukan karena jenis pekerjaanya melainkan kompetensi yang dimilikinya.

2. Kontribusi Perempuan dalam Penciptaan PendapatanSemakin Besar, perempuan yang disubordinasikan sebagai pekerja yang tidak dibayar seiring dengan perkembangan dan transformasi sosial memudahkan untuk berperan di ranah publik dan mendapatkan pekerjaan yang dibayar sesuai dengan keahliannya.

3. Pemberdayaan gender Tingkat Provinsi Merata antara KBI dan KTI, komitmen negara untuk meningkatkan pembangunan yang berbasis gender semakin tinggi, hal ini dibuktikan dengan Pemberdayaan perempuan dan program yang berpihak pada pro gender semakin meningkat (Buku Pembangunan Gender kementerian pemberdayaan perempuan dan anak tahun 2016: 41-54).

Kabupaten Purbalingga, daerah yang saat ini lebih dikenal dengan industri bulu mata dan rambut palsu mengalami dinamimisasi peran gender yang unik dengan kehidupan kaum buruh yang bersifat komunal dan tipologi industri yang sama yaitu bulu mata dan rambut palsu. Buruh perempuan tidak hanya bekerja sebagai buruh industri yang bersifat modern tetapi juga usaha plasma yang hampir menyebar diseluruh wilayah Kabupaten Purbalingga. 
Dinamisasi peran gender tersebut diawali dengan penyerapan tenaga kerja pada industri yang lebih membutuhkan perempuan dan menyebabkan segmentasi dan kesenjangan yang tinggi dalam kesempatan mendapatkan pekerjaan antara perempuan dan laki-laki.Kondisi ini membuat laki-laki merasa terpinggirkan dari persaingan dalam bekerja karena tidak terserap oleh industri. Bermula dari sinilah laki-laki tidak dapat berperan sebagai pencari nafkah bagi keluarga, dari sini pula istilah pamongpraja populer pada masyarakat di Kabupaten Purbalingga, laki-laki berperan dalam ranah domestik dari mengantar dan menjemput istri bekerja, merawat anak, memasak dan membersihkan rumah.Hasil wawancara dengan Mas Fd salah satu suami buruh dan mantan buruh yang menjadi pembina koperasi buruh adalah sebagai berikut;

"Buruh hanya dua pilihannya mendominasi atau terekploitasi mendominasi terjadi pada kalangan buruh yang sudah memiliki jabatan tertentu seperti suvervisor atau mandor dengan anak buah yang cukup banyak kondisi ini membuat psikologis terbawa ke rumah, pengalamanya membina koperasi buruh hampir $70 \%$ perempuan terekploitasi suami menikmati menjadi pengangguran dan istri bekerja. Suami momong bocah dan keperluan domestik lainnya, seperti mencuci, ngepel, yang membuat sebagian besar buruh sering curhat dengan mengungkapkan permasalahan rumah tangganya.

Data berikut juga menunjukkan penyerapan tenaga kerja pada sektor industri yang lebih memberi kesempatan pada perempuan;

Tabel 2. Persentase Penduduk Yang Bekerja Menurut Status Pekerjaan Utama dan Jenis Kelamin Kabupaten Purbalingga Tahun 2014

Sumber : Sakernas 2014

\begin{tabular}{lccc}
\hline \multicolumn{1}{c}{ Lapangan Pekerjaan Utama } & \multicolumn{3}{c}{ Jenis Kelamin } \\
& Laki-laki & Permpuan & Laki+Permp \\
\multicolumn{1}{c}{$(1)$} & $(2)$ & $(3)$ & $(4)$ \\
\hline $\begin{array}{l}\text { Berusaha sendiri } \\
\begin{array}{l}\text { Berusaha dibantu buruh tidak } \\
\text { tetap/buruh tdk dibayar }\end{array}\end{array}$ & 14.15 & 11.29 & 12.91 \\
$\begin{array}{l}\text { Berusaha dibantu buruh tetap/ } \\
\text { buruh dibayar }\end{array}$ & 28.80 & 11.95 & 21.53 \\
$\begin{array}{l}\text { Buruh/Karyawan/Pegawai } \\
\text { (1) }\end{array}$ & 32.03 & 0.90 & 3.45 \\
& & 44.51 & 37.41
\end{tabular}




\begin{tabular}{lccc}
\hline \multicolumn{1}{c}{ Lapangan Pekerjaan Utama } & \multicolumn{3}{c}{ Jenis Kelamin } \\
& Laki-laki & Permpuan & Laki+Permp \\
Pekerja Bebas Pertanian/Non & 16.48 & 6.57 & 12.20 \\
$\begin{array}{l}\text { Pertanian } \\
\text { Pekerja Keluarga/Tak Dibayar }\end{array}$ & 3.17 & 24.79 & 12.50 \\
\hline \multicolumn{1}{c}{ Jumlah } & 100,00 & 100,00 & 100,00 \\
\hline
\end{tabular}

Penduduk yang bekerja menurut status pekerjaan utama pada tabel 2 terlihat bahwa sebanyak 37,41 persen penduduk yang bekerja adalah berstatus sebagai buruh/karyawan/pegawai dengan persentase laki-laki 32,03 persen dan perempuan 44,51 persen. Mayoritas perempuan yang bekerja di Kabupaten Purbalingga adalah sebagai buruh dan juga sebagai pekerja keluarga yaitu 24,79 persen. Sementara penduduk laki-laki selain sebagai buruh, sebagian besar juga berstatus sebagai berusaha dibantu buruh tidak tetap/tidak dibayar yaitu 28,80 persen yang bekerja di lapangan pekerjaan pertanian.

Perubahan lebih signifikan tercermin dalam perubahan perilaku produktif yang bergeser ke arah individual dan merubah posisi dominan keluarga cenderung terjadi pada masyarakat industi baru. Istri mulai terbuka pola pikirnya untuk tidak menggantungkan diri pada suami, demikian pula dengan prinsip kemandirian, seorang istri tidak harus di rumah harus bisa beraktivitas di luar dan mampu memperoleh apa yang menjadi keinginan bersama, baik nafkah maupun aktivitas publik yang dapat dilakukan oleh perempuan. Sejauh mana perubahan perilaku produksi dari masyarakat industri baru dapat didiskripsikan dalam tabel berikut:

Tabel 3 Perubahan Perilaku Produksi suami istri dalam keluarga buruh

\begin{tabular}{|c|c|c|c|c|}
\hline No & Pertanyaan & Ya & Tidak & $\begin{array}{l}\text { Kadang- } \\
\text { kadang }\end{array}$ \\
\hline 1 & $\begin{array}{l}\text { Buruh perempuan/istri lebih ban- } \\
\text { yak kesempatan memperoleh } \\
\text { pekerjaan dari pada suaminya }\end{array}$ & 71,4 & 16,5 & 12,1 \\
\hline 2 & $\begin{array}{l}\text { Buruh perempuan/istri yang men- } \\
\text { cukupi semua kebutuhan keluarga }\end{array}$ & 63,2 & 14,0 & 22,9 \\
\hline 3 & $\begin{array}{l}\text { Buruh perempuan/istri menjadi } \\
\text { tumpuan ekonomi keluarga }\end{array}$ & 60,6 & 17,8 & 21,6 \\
\hline 4 & $\begin{array}{l}\text { Buruh perempuan/istri lembur } \\
\text { kerja untuk mendapatkan peng- } \\
\text { hasilkan }\end{array}$ & 10,8 & 70,8 & 18,4 \\
\hline
\end{tabular}

Sumber: Data Primer yang Diolah Tahun 2017 
Sesuai dengan responden yang terdiri dari buruh perempuan dan lakilaki yang bekerja di industri rambut dan bulu mata palsu yang berjumlah 315 , disebutkan terjadinya perubahan perilaku produksi suami dan istri dalam keluarga buruh, buruh perempuan lebih banyak memperoleh pekerjaan, mencukupi kebutuhan keluarga, menjadi tumpuan ekonomi keluarga serta perempuan merasa berkeinginan untuk memperoleh upah tambahan melalui lembur kerja. Jawaban responden apabila dikaitkan dengan pandangan Usman (2010: 156) menunjukkan peran produksi keluarga yang awalnya sebagai pusat produksi bergeser ke unit produksi, masyarakat yang awalnya adalah berproduksi dalam masyarakat agraris bergeser ke unit produksi karena sekedar unit income untuk memperoleh penghasilan dari bekerja sebagai buruh.Pada masyarakat industri juga beban kerja bergeser dari keluarga ke individu sebagai pekerja, istri sebagai individu mengalami pergeseran peran dari individu yang bekerja di unit produksi dan tidak dibayar berubah menjadi individu yang bekerja di domain publik dan memperoleh penghasilan.Perubahan peran ekonomi dalam keluarga industri baru cenderung mengalami pergeseran yang disebut dengan pola equalitarian yang tidak seimbang, suami bisa jadi sebagai kepala keluarga tetapi tidak sebagai superordinan, yaitu posisi yang paling dominan dalam keluarga.

\section{Peningkatan Partisipasi Kerja Perempuan dan Tata nilai Baru}

Industri dan pergeseran peran perempuan menjadi catatan penting, hal ini menunjukkan peran perempuan dalam pembangunan yang lebih luas ditandaidengan semakin terbukanya peluang perempuan untuk berpartisipasidalam penciptaan output perekonomian dan pengambilan keputusan.Kapabilitas perempuan sebagai bagian dariangkatan kerja yang mempunyai peranan yang penting juga menjadi perkembangan positif di tengah budaya patriarki yang masih menjadi nilai dominan di masyarakat. Perlahan tapi pasti perspektif patriarki yang menganggap perempuan berperan di ranah reproduktif sedikit berubah dengan adanya peran perempuan yang strategis ditunjukkan dengan kemampuan dan profesionalisme di tempat kerja.(Said, et.al: 62).Pergeseran status perempuan dilihat dari tingkat partisipasi angkatan kerja secara konsisten menunjukkan peningkatan dari 
tahun ke tahun.Hal ini membawa pengaruh positif terhadap nasib perempuan dalam angkatan kerja. Peningkatan partisipasi kerja perempuan dapat dilihat pada tahun 2005 dan tahun 2015 adalah sebagai berikut:

Tabel 4. TPAK dan Persentase Penduduk yang Bekerja (persen), 2005 dan 2015

\begin{tabular}{lcccc}
\hline Keterangan & \multicolumn{2}{c}{2005} & \multicolumn{2}{c}{2015} \\
\cline { 2 - 5 } & Laki-Laki & Perempuan & Laki-Laki & Perempuan \\
\hline $\begin{array}{l}\text { Tingkat Partisipasi Angka- } \\
\text { tan Kerja (TPAK) }\end{array}$ & 84,94 & 49,41 & 82,71 & 48,87 \\
$\begin{array}{l}\text { Persentase Penduduk yang } \\
\text { Bekerja terhadap Pen- } \\
\text { duduk Usia 15 tahun Keat- }\end{array}$ & 77,05 & 41,29 & 78,33 & 45,76 \\
as
\end{tabular}

Sumber: Survei Angkatan Kerja November 2005 dan Agustus 2015, BPS

Peningkatan jumlah perempuan yang bekerja akan terus terjadi seiring dengan peningkatan tingkat pendidikan dan kapasitas perempuan. Potensi perempuan sebagai sumber daya manusia dalam pembangunan cukup besar mengingat populasinya hampir sama dengan laki-laki. Tingkat Partisipasi Angkatan Kerja (TPAK) perempuan yang hanya mencapai hampir 50 persen memberikan indikasi bahwa masih terdapat potensi sumber daya manusia yang cukup besar yang belum termanfaatkan.

Data tersebut memberikan informasi bahwa angkatan kerja perempuan yang meningkat dapat dijelaskan dalam 2 (dua) pandangan teoritik yaitu pertama dari perspektif neo-klasik yang menganggap produktivitas pekerja di tentukan oleh faktor biologis dan bersifat deterministik.Jenis kelamin menentukan dalam produktivitas kerja sehingga perlu dipisahkan antar lakilaki dan perempuan dalam kesempatan bekerja. Kedua adalah segmentasi pasar kerja yang menganggap perempuan cenderung terkonsentrasi pada pekerjaan sekunder karena dipandang kurang memiliki ketrampilan atau keahlian oleh karena itu ada perbedaan antara laki-laki dan perempuan dalam dunia kerja (Effendi, 2013: 9). Pandangan teoritik tersebut masih menganggap perempuan walaupun memiliki kesempatan bekerja, tetapi masih di tempatkan pada pekerjaan sekunder, hal ini dibuktikan dengan tingkat upah yang rendah. Mengingat hal demikian setidaknya perlunya regulasi yang mengatur keseteraan dalam kesempatan kerja terutama di tingkat upah. 
Sementara itu alasan yang menyebabkan tingginya tingkat partisipasi angkatan kerja wanita dalam kegiatan ekonomidisebabkan oleh beberapa hal yaitu:

1. Adanya perubahan pandangan dan sikap dalammasyarakat tentang sama pentingnya pendidikan bagi kaum pria dan wanita serta semakin disadari perlunya kaum wanita ikut berpartisipasi dalam pembangunan,

2. Adanya kemauan wanita untuk mandiri dalam bidang ekonomi yaitu berusaha membiayai kebutuhan hidupnya (dan juga kebutuhan hidup orang-orang yang menjadi tanggungannya) dengan penghasilannya sendiri,

3. Adanya kebutuhan untuk menambah penghasilan keluarga,

4. Makin luasnya kesempatan kerja yang bisa menyerap tenaga kerja wanita, misalnya tumbuhnya industri kerajinan tangandan industri ringan lainnya. (Setyowati, 2009: 216)

Peningkatan angkatan kerja pada masyarakat industri baru di Kabupaten Purbalingga terlihat dari data tentang pergeseran struktur ekonomi yang cenderung berubah di Kabupaten Purbalingga selama sepuluh tahun akhir terjadinya peningkatan partisipasi kerja perempuan. Adapun data Rencana Pembangnan Jangka Menengah Daerah (RPJMD) tahun 2016-2021 adalah sebagai berikut:

Tenaga kerja laki-laki dan perempuan lebih mendominasi di manufaktur dilihat berdasar jenis kelamin proporsi perempuan lebih banyak yang bekerja di manufaktur (industri) yaitu sebesar 45,60 persen, sedangkan tenaga kerja laki-laki di manufaktur 37,46 persen. Kondisi ini sesuai dengan keadaan ketenagakerjaan di Kabupaten Purbalingga dimana industri pengolahan khususnya industri rambut palsu dan industri bulu mata palsu di Purbalingga banyak merekrut tenaga kerja perempuan. Sekitar 37,41 persen penduduk yang bekerja adalah berstatus sebagai buruh/karyawan/pegawai dengan persentase laki-laki 32,03 persen dan perempuan 44,51 persen. Mayoritas perempuan yang bekerja di Kabupaten Purbalingga adalah sebagai buruh dan juga sebagai pekerja keluarga yaitu 24,79 persen. Sementara penduduk laki-laki selain sebagai buruh, sebagian besar juga berstatus sebagai berusaha dibantu buruh tidak tetap/tidak dibayar yaitu 28,80 persen yang bekerja di lapangan pekerjaan pertanian.(RPJMD Kabupaten Purbalingga Tahun 2016-2021) 
Data tersebut menunjukkan industri rambut rambut dan bulu mata palsu telah merubah struktur ekonomi di Kabupaten Purbalingga.Perubahan struktur ekonomi yang sudah berlangsung lama sedikit banyak telah merubah perspektif perempuan dalam menjalankan peran publiknya sebagai fakta sosial yang tidak bisa dihindari.

Buruh industri rambut dan bulu mata palsu dalam perspektif peran publik bersumber pada pembagian peran tradisional yang tidak lepas dari budaya dan pola pikir masyarakat saat ini. Oleh karena itu anggapan terhadap buruh perempuan dengan latar belakang pendidikan yang rendah masih berpijak pada stagnasi cara pandang sesuai dengan budaya dan steoretipe gender dimana peran perempuan di ranah publik masih dihadapkan pada berbagai persoalan. Paling tidak perempuan sebagai pekerja industri dalam menjalankan peran publiknya masih dihadapkan pada situasi, 1) buruh perempuan di ranah publik merupakan kelompok yang memperoleh dampak dari sistem dominasi dalam lingkaran budaya, di dalam industri/pabrik perempuan memperoleh perlakuan dominasi dari majikan, suvervisor atau atasannya, 2) sementara di tingkat internal keluarga seorang buruh perempuan mendapat perlakuan didominasi oleh suaminya walaupun istri adalah sebagai pencari nafkah, 3 ) posisi buruh perempuan tidak sama dengan buruh laki-laki walaupun buruh perempuan mempunyai status sama yaitu sebagai buruh,4) buruh perempuan memiliki harapan bahwa dunia kerja akan meningkatkan status ekonomi dan perubahan status sosial di masyarakat. (Suharsih, 2013: 16-19). Sementara dari hasil wawancara yang dilakukan pada informan Mas Fd adalah sebagi berikut;

“......kalau perempuan kerja, laki - lakinya nggak kerja tapi dia tahu diri, maka yang terjadi adalah laki - laki yang bertukar peran dia mengerjakan urusan rumah tangga. Kalau kemudian dia tidak bertukar peran maka yang terjadi adalah cekcok. Ini mengindikasi bahwa laki lakinya bukan sebagai korban tapi hanya pertukaran peran. Harusnya perceraian tidak tinggi.

Hasil wawancara menunjukkan ada persoalan pada laki-laki pada saat pergantian peran, tidak adanya kesadaran gender dalam menjalankan peran masing-masing. Pada saat istri bekerja dan mendapatkan penghasilan yang 
layak, tidak ada saling pemahaman antara keduanya antara suami dan istri sehingga terjadi ketidakharmonisan dalam keluarga.Oleh karena itu persoalan buruh perempuan dan peran publiknya menjadi dinamika sosial yang unik yang dialami oleh masyarakat industri baru di Kabupaten Purbalingga.

Budaya masyarakat industri yang terspesialisasi tentunya membawa nilai baru sebagai orang pabrikan atau orang dengan sebutan populer Ikatan Kuli Idep(IKIP), atau ikatan pekerja bulu mata palsu, nilai baru tersebut adalah cerminan sistem kapitalis industri dengan sistem kerja yang ketat, terjadwal dengan baik menghargai waktu sebagai proses produksi yang penting. Sementara dari sisi buruh perempuan tentunya akan terlihat dari simbol budaya yang digunakan, visi kehidupan buruh industri, pilihan gaya hidup dan perkawinanpun melalui proses dialog dengan identitas lama yang terus berubah.Perempuan perlahan menjadi sosok yang mampu mengerjakan peran publik dengan sadar, dan berusaha untuk membuat alternatif manajemen keluarga seiring dengan peran baru perempuan yang mulai diperankan. Perempuan dengan peningkatan peran publiknya secara tidak langsung memberikan ruang pemikiran untuk menjadi perempuan yang mandiri tidak tergantung pada pasangan atau siapapun.Inilah industrialiasi yang mampu merubah wajah perempuan di Kabupaen Purbalingga menjadi perempuan mandiri dan memiliki sumber ekonomi yang bisa diandalkan.

\section{Kebijakan Ramah Perempuan dan Anak bersifat Administratif bukan substantif}

Industri rambut dan bulu palsu secara ekonomi mengurangi jumlah pengangguran, kesejahteraan meningkat karena buruh perempuan mendapatkan penghasilan, tetapi peningkatan dalam kesejahteraan buruh tidak diimbangi dengan tertanganinya persoalan yang muncul dalam keluarga buruh perempuan. Terutama menyangkut masalah pengasuhan anak dari menyusui sampai mendampingi anak tumbuh kembang dalam bermain belajar maupun bermain, dan anggapan dominasi perempuan terhadap laki-laki. Permasalahan ini muncul seiring dengan peran baru perempuan yang tidak diimbangi kesadaran gender dalam keluarga, akibatnya muncul eksploitasi terhadap perempuan dan anak dalam perspektif yang berbeda. 
Kekerasan dalam rumah tangga, ketidakharmonisan keluarga dan peningkatan gugat cerai pada keluarga buruh, serta timbulnya penyimpangan disorientasi seksual pada buruh perempuan menjadi warna diskursus perempuan dan industri di Kabupaten Purbalingga.Data berikut menyajikan kasus kekerasan yang terjadi di Kabupaten Purbalingga.

Tabel 5 Jumlah Kasus Kekerasan Berbasis Gender dan Anak di Kabupaten Purbalingga

\begin{tabular}{lllll}
\hline \multirow{2}{*}{ No. } & Bentuk Kekerasan & \multicolumn{3}{c}{ Tahun } \\
\cline { 3 - 5 } 1 & Fisik & 2014 & 2015 & 2016 \\
2 & Psikis & 3 & 2 & - \\
3 & Seksual & 6 & 4 & 2 \\
4 & Eksploitasi & 8 & 7 & 5 \\
5 & Penelantaran & - & - & - \\
6 & Trafiking & - & - & - \\
7 & Lainnya & 1 & - & - \\
Jumlah & - & 3 & 3 \\
\hline
\end{tabular}

Sumber: Tim Harapan Kabupaten Purbalingga 2016

Selain itu ruang publik yang belum berpihak pada perempuan masih menjadi persoalan yang belum terpikirkan oleh pemerintah daerah. Kondisi ini diperburuk dengan kesadaran komunitas untuk peduli terhadap masalah gender dalam keluarga untuk menyediakan layanan penitipan anak, pengasuhan anak belum optimal bahkan tidak tersesedia.Berdasarkan pengamatan dilapangan buruh pabrik yang memiliki anak dititipkan pada orang tuanya atau kakek dan neneknya, atau pada suaminya yang tidak bekerja karena sarana untuk mendukung kepedulian terhadap anak belum terpenuhi. Berdasarkan data BPS Kabupaten Purbalingga Tahun 2016, jumlah anak usia PAUD dan TK sekitar 16.894 anak dengan sarana 513 TPA dan TK. Khusus di Kecamatan Purbalingga sebagai sentra industri rambut hanya tersedia 34 TPA dan TK dengan jumlah anak sekitar 1893. Kondisi ini menunjuk sarana prasarana yang tersedia belum optimal

Berangkat dari permasalahan tersebut perlunya strategi pemecahan permasalahan buruh perempuan pada masyarakat industri baru, langkah pertama adalah political will dan komitmen negara untuk mencapai kesetaraan dan keadilan gender melalui kebijakan ramah perempuan menjadi 
perhatian yang di atur dalam konstitusi UUD NRI 1945 yang menjamin dan melindungi hak asasi manusia tanpa adanya pembedaan baik ras, agama, jenis kelamin maupun gender. Selain tersurat dalam konsitusi ditegaskan dalam GBHN sejak tahun 1978, di tahun yang sama Presiden membentuk Kementerian Muda Urusan Peranan Wanita (MENMUD UPW) yang merupakan cikal bakal dari Kementerian Pemberdayaan Perempuan dan Perlindungan Anak. Pada tahun 1984, Pemerintah Indonesia meratifikasi "konvensi perempuan" yakni Convention on the Elemination of All Forms of Discrimination Againts Women (CEDAW) menjadi Undang-Undang No. 7 tahun 1984. Peraturan perundangan-undangan yang mengatur masalah hak perempuan mendapat perhatian dari pemerintah, upaya pemerintah untuk menghilangkan diskriminasi dan penghapusan kekerasan dalam rumah tangga, perlindungan hukum terhadap korban kekerasan dalam rumah tangga, peraturan perundangan yang disusun dengan perspektif kesetaraan gender terus ditingkatkan. (Kania, 2015: 732-733). Selain itu perlunya dirumuskan peraturan daerah yang berpihak pada perempuan dan anak berupa regulasi Kabupaten Layak Anak (KLA) dan kebijakan family care yang mengembangkan sarana penitipan anak berbasis komunitas.

Langkah kedua adalah di tingkat daerah diperlukan tingkat komitmen yang sama untuk kebijakan ramah perempuan dan anak, di Kabupaten Purbalingga untuk mengantisipasi dampak industrialisasi telah dirumuskan Peraturan Daerah Kabupaten Purbalingga Nomor 2 Tahun 2017 tentang penyelenggaraan perlindungan korban kekerasan berbasis gender dan anaktujuan penyelenggaraan perlindungan korban berbasis gender dan anak adalah untuk: a) mencegah segala bentuk kekerasan berbasis gender dan kekerasan terhadap anak, yang terjadi di lingkup rumah tangga dan/ atau masyarakat; b) memberikan perlindungan berupa layanan pengaduan, layanan kesehatan, layanan rehabilitasi sosial, layanan bantuan dan penegakan hukum, serta layanan pemulangan dan reintegrasi sosial; dan c) mengupayakan peningkatan partisipasi masyarakat.Perda tersebut diharapkan sebagai payung hukum yang dapat melindungi perempuan dan anak dalam hal kekerasan baik yang dilakukan di lingungan keluarga maupun masyarakat.Perda tersebut bersifat pendidikan, pencegahan dan tindakan 
terhadap korban kekerasan.Muatan perda tersebut menjadi acuan dalam membangun media yang efektif dalam kepedulian pemerintah daerah untuk mengantisipasi dinamika sosial yang semakin tak terkendali.

Selanjutnya langkah yang ketiga adalah Rencana Kerja Pemerintah Daerah (RKPD) Tahun 2017 orientasi pada peningkatan kualitas hidup perempuan dilaksanakan melalui berbagai bidang pembangunan, diantaranya dengan meningkatkan partisipasi perempuan yang bekerja di lembaga swasta. Rasio kesempatan kerja terhadap penduduk usia kerja 15 tahun ke atas periode Tahun 2010-2017 bersifat fluktuatif dan cenderung meningkat dari $52,52 \%$ menjadi $67,31 \%$. Secara absolut juga mengalami peningkatan dari 337.714 orang menjadi 443.845 orang.

Langkah kebijakan yang ditempuh oleh pemerintah daerah belum menunjukan optimalisasi permasalahan gender dan anak. Permasalahanya adalah masih dijumpai permasalahan di tingkat domestik maupun publik. Di tingkat domestik belum adanya penanganan masalah penanganan anak, pelayanan penitipan anak, kekerasan dalam rumah tangga dan pandangan gender yang masih kuat menempatkan laki-laki dominan, walaupun wacana sebaliknya juga cukup kuat yaitu perempuan mendominasi lakilaki dalam aksesibilitas dan kesempatan kerja.Semantara itu di tingkat publik perempuan yang bekerja belum mendapatkan perlindungan dari pemerintah daerah secara optimal, upah yang murah, kekerasan dalam bekerja, dan perlindungan kesehatan reproduksi yang terbaikan.

Di tingkat daerah seringkali kebijakan ramah perempuan dikaitkan dengan kekuasaan yang dibungkus dengan berbagai media, termasuk tubuh perempuan digunakan sebagai alat politik, mobilisasi dan mempertahankan status quo. Kekuasaan untuk meraih empati dan dalih agama menggunakan tubuh perempuan secara formal dengan regulasi yang sengaja dirumuskan oleh kekuasaan untuk mengatur tubuh perempuan.Rumusan regulasi tersebut dalam bentuk UU dan Perda di tingkat daerah, UU tentang pornografi, Perda tentang pelacuran sebagai bentuk campur tangan negara atau kekuasaan untuk mengatur tubuh perempuan sebagai obyek.Tubuh perempuan dianggap sebagai logika penertiban pelacuran dan pornografi yang harus diatur sedemikian rupa seolah perempuan adalah sumber dari 
kemaksiatan dan moralitas yang harus dikendalikan (Yuliani, 2011: 164$165)$.

Kajian Mosse (2004: 48-49) tentang ibu dan ibu rumah tangga, gender, kerja reproduktif dan produktif menyebutkan ketidakpedulian negara terhadap perempuan karena alasan kemiskinan mengakibatkan tekanan terhadap perempuan semakin tinggi. Perempuan dituntut untuk mencari nafkah secara intensif, padahal keterbatasan karena budaya patriarki, mobilitas, waktu dan akses menyebabkan perempuan bekerja dengan sangat murah, baik dalam bidang pertanian, industri maupun pekerja rumahan. Sebagian perempuan tidak mampu mendapatkan pekerjaan secara formal, akibatnya pekerjaan apa saja yang penting mendapatkan upah. Negara seharusnya hadir untuk mengatur dan memberikan kesempatan yang sama melalui regulasi yang tepat tentang pembagian kerja tidak hanya berpedoman pada pembagaian kerja secara seksual.

Pandangan dari kajian tersebut seolah menegaskan terbukanya lapangan pekerjaan bagi perempuan di Kabupaten Purbalingga menjadi komoditas pemerintah daerah untuk meningkatkan kesejahteraan masyarakat, tetapi kenyataanya masih banyak masalah yang perlu ditangani dari kebijakan ramah perempuan dan anak yang belum menyentuh pada permasalahan sesungguhnya untuk menciptakan kesetaraan dan keadilan gender. Pembangunan tidak hanya dinikmati oleh sebagian warganya tetapi mampu menciptakan keseimbangan dan keadilan bersama.

Sesuai dengan diskripsi dari penjelasan dalam pembahasan dapat diskusikan tentang peran gender perempuan senantiasa bersifat kontradiktif dengan kenyataan peran gender laki-laki yang selalu dominan. Konstruksi wacana akan selalu menganggap laki-laki sebagai main breadwinner sesuai dengan norma masyarakat patriarki dan berkuasa atas perempuan. Dominasi laki-laki seolah-olah sudah menjadi kesadaran kolektif yang dianggap sebagai kodrat, given dan absolut. Kondisi demikian, merupakan proses hegemoni wacana budaya patriarki, yang dilanggengkan dan dipertahankan, direproduksi dalam wacana yang didukung oleh institusi agama dan negara (Bourdeu, 2010: 135).

Namun demikian seiring dengan perubahan dan kondisi global yang mengalami krisis, dan kehadiran industri sampai di tingkat daerah termasuk di Kabupaten Purbaligga, peran gender perempuan tampil berbeda 
dengan wajah baru perempuan yang memiliki identitas dengan mobilitas dan kesuksesan profesional di tengah realitas posisi perempuan yang tersubordinasi dan terdiskriminasi dalam menjalankan peran gendernya. Faktor-faktor yang menentukan peningkatan status perempuan dalam masyarakat modern dianalisis dalam aspek regulasi, pendidikan, ekonomi dan sektor pekerjaan, kesadaran dan partisipasi politik, kesadaran akan hak-hak perempuan. Bidang pendidikan menjadi faktor dominan dalam peningkatan peran perempuan(Singh 2014: 59-62)

Partisipasi angkatan kerja perempuan menjadi peningkatan yang substansial kemajuan perempuan terutama di negara-negara Eropa Timur Tengah, dan kebangkitan ekonomi perempuanterjadi pertama kali di negaranegara Nordik yang mengalami perubahan dalam ketenagakerjaan wanita dengan pola kerja wanita yang baru, wanita tidak menarik diri dari pasar tenaga kerja setelah menikah atau menjadi ibu, tetapi tetap digunakan hingga usia pensiun (Olah, Livia Sz Rudolf Richter and Irena E. Kotowska, 2014: 1-27). Peningkatan kemandirian dan perluasan peran baru perempuan ditingkat global dengan menjadi penyedia utama ekonomi untuk keluarga, serta transformasi peran pria dengan keterlibatan yang lebih luas dalam tanggung jawab keluarga, terutama merawat, mengasuh dan mendidik anak-anak berimplikasi pada dinamika pembagian peran dalam keluarga yang semakin terbuka. Peran gender baru telah merubah pula pola keluarga dalam hubungan gender, nilainilai dan sikap yang terkait dalam keluarga telah menjadi lebih cair, berubah secara dinamis. Perubahan peran gender dalam keluarga juga mempengaruhi konteks kebijakan yang berbeda dan mempengaruhi pengambil kebijakan dalam mengkonstruksi peran gender untuk dinamisasi kehidupan keluarga.

Konteks kebijakan dalam menghadapi dinamisasi perubahan peran gender perempuan dituntut kebijakan yang mampu beradaptasi sesuai dengan kebutuhan dan permasalahan yang terjadi. Dinamika perempuan dan industri di Kabupaten Purbalingga menjadi wacana yang cukup menarik karena konstruksi yang dibangun adalah munculnya perempuan yang mandiri, berpenghasilan dan laki-laki yang tidak berdaya karena struktur kesempatan pekerjaan yang tidak berpihak.Akibatnya muncul permasalahan yang klasik tetapi perspektif yang dibangun untuk mengatasi masalah tersebut berbeda, 
oleh karena itu kebijakan untuk mengatasi masalah implikasi industri dan dinamisasi peran gender adalah kebijakan family care yang didukung tidak hanya negara tetapi pelaku industri terutama perusahaan rambut dan bulu mata palsu secara bersama membangun komunitas peduli masalah gender dan anak yang terintegratif.

\section{Simpulan}

Kehadiran industri rambut dan bulu mata palsu berimplikasi positif terhadap perempuan dengan semakin terbukanya aksesibilitas dan kesempatan memperoleh pekerjaan semakin jelas. Perempuan yang biasanya diasumsikan sebagai pekerja domestik dan tidak dibayar mendapatkan kesempatan untuk memperoleh penghasilan yang layak sebagai pekerja buruh. Namun sisi lain keberadaan industri rambut dan bulu mata palsu menyebabkan permasalahan baru, yaitu kesenjangan penyerapan tenaga kerja yang tinggi antara perempuan dan laki-laki, dan implikasinya adalah masalah pengasuhan anak, disharmonisasi keluarga, kekerasan terhadap perempuan dan anak. Sementara itu perempuan dalam dunia industri juga masih dihadapkan pada persoalan feminisasi pekerjaan yang menghendaki perempuan sebagai tenaga kerja yang murah, karena dianggap berbeda dengan pekerja laki-laki.Masalah kesenjangan dan feminisasi tenaga kerja perempuan mengakibatkan dinamisasi masyarakat berjalan tidak sesuai dengan tantanan nilai sosial yang berkembang.Akibatanya muncul problem sosial di tingkat keluarga maupun sosial.

Oleh karena diperlukan kebijakan dalam pembangunan tidak sekedar menyelesaikan penyerapan tenaga kerja tetapi memperhatikan keberlanjutan harmonisasi nilai-nilai lokal. Kebijakan ramah perempuan dan anak tidak hanya menyentuh pada aspek regulasi hukum tetapi substansi menyelesaikan masalah ketimpangan gender di masyarakat industri baru.Keterlibatan komunitas peduli terhadap masalah perempuan dan anak di lingkungan industri lebih dibutuhkan dibandingkan dengan kebijakan yang sifatnya topdown dari pemerintah daerah. Di tingkat industri pentingnya program Corporate Social Responsibility (CSR) untuk fasilitas layanan publik berupa ruang laktasi, penitipan anak dan ruang konsultasi keluarga. Harapannya laki-lakipun mampu berperan dan berpikir terbuka dalam dinamika peran gender yang berubah. 


\section{Daftar Pustaka}

Apriando, Tommy, 2013, “Teror Kekerasan di Tempat Kerja: Ironi dan Solusi” dalam Rifka Media, No 53 Mei-Juli 2013.

Aziz, Asmaeni, 2007, Feminisme Profetik, Kreasi Wacana, Cetakan I, halaman: 99, Yogyakarta.

Bourdieu, Pierre, 2010, Dominasi Maskulin, Jalasutra, Cet. I Juli, Yogyakarta.

Budiman, Kris, 2006, Transisi Ruang Sosial Perempuan: Domestik Ke Publik, Perempuan Di Rumah-(Ber) Tangga, Bunga Rampai Sangkan Paran Gender, Cetakan Ke III, halaman: 145, Pustaka Pelajar, Yogyakarta.

Byerne, Jennifer, \& Aine M.Humble, 2006, Atlantic Research Centre For Family-Work Issues Mount Saint Vincent University.

Chu \& Charles Posner, 2013, The State of Women in AmericaA 50-State Analysis of How WomenAre Faring Across the Nation, Center for America Progress, September 2013 dalam www.americanprogress.orgAccessed: 26-06-2018 03:27 UTC

Dhewy, Anita, 2017, "Perempuan dan Kebijakan Publik" dalam Jurnal Perempuan, Vol 22 No. 1 Februari, hal. 5, Jakarta

Effendi, Tadjuddin Noer, 2013, "Ketidaksetaraan Gender di Pasar Kerja" dalam Rifka Media, No 53, halaman 7-9, Mei-Juli 2013.

Inglehart\&Pippa Norris, 2003, Rising Tide Gender Equality and Cultural hangearound theWorld, Cambridge University Press: Cambridge, New York, Melbourne, Madrid, Cape Town, Singapore, Sao Paulo.

Kania, Dede, "Hak Asasi Perempuan dalam Peraturan PerundangUndangan Di Indonesia The Rights of Women in Indonesian Laws and Regulations” dalam Jurnal Konstitusi, Vol. 12, No. 4, Desember 2015. hal.716-733

Kymlicka, Will, 2014, Pengantar Filasafat Politik Kontemporer Kajian Khusus Asas Teori-Teori Keadilan, terjemahan, Cetakan I, Pustaka Pelajar Yogyakarta.

Milnor, Kristina, 2005, "Gender, Domesticity, and the Age of Augustus: Inventing Private Life" dalam Oxford Studies in Classical Literature and Gender Theory. Oxford: Oxford University Press, 2005.

Mosse, Julia Cleves, 2004, Gender dan Pembangunan, Cetakan ke-iv, Pustaka Pelajar Yogyakarta. 
Olah, Livia Sz Rudolf Richter and Irena E. Kotowska, 2014, "Changing families and sustainable societies: Policy contexts and diversity over the life course and across generations Changing families and sustainable societies: miliesAndSocieties" dalam Working Paper Series, Policy contexts and diversity over the life course and across generations A project funded by European Union's Seventh Framework Programme under grant agreement no. 320116

Poire, BAL 2006, Family communication: nurturing and control in a changing world,Sage Publications, London. Paperback, 345.

Puspita, Dyah Retna, Rin Rostikawati dan Lilils SS, ”Model Penyuluhan Berbasis Gender Dalam Mencegah Kekerasan Dalam Rumah Tangga di Kabupaten Purbalingga " dalam Jurnal Dinamika Hukum Vol. 14 No. 3 September 2014, hal. 419-421

Rofia’ah, Siti, 2015, “Membangun Pola Relasi Gender Berbasis Kesetaraan dan Keadilan Gender" dalam Jurnal Muwazah, Vol 7 No 2 Desesember 2015 hal. 93-107.

Said, Ali dkk, 2016, Statistik Gender Tematik Potret Ketimpangan Gender Dalam Ekonomi Kerjasama Kementerian Pemberdayaan Perempuan Dan Perlindungan Anak Dengan Badan Pusat Statistik, Jakarta.

Setiansah, Mite, Shinta Prastyanti, 2011, “Tidak Ada Pekerjaan untuk LakiLaki di Purbalingga (Menguak Sisi Gelap Pembangunan Masyarakat di Kabupaten Purbalingga, Acta Diurnal, Vol.7 No.2 Jurnal Ilmu Komunikasi Fisip Unsoed, hal. 37-45.

Setyowati, Eni, 2009, "Analisis Tingkat Partisipasi Wanita Dalam Angkatan Kerja Di Jawa Tengah Periode Tahun 1982-2000" dalam Jurnal Ekonomi Pembangunan Vol. 10, No.2, Desember 2009, hal. 215 - 233

Singh, Ranjita, 2014, "Status of Women in Today's Society" dalam International Journal of Humanities and Social Science Invention tersedia secara online dalam www.ijhssi.org Vol 3 Issue 2 February. 2014,pp. 5962

Suharsih, Arsih, 2013, "Buruh Perempuan, Sudah jatuh Tertimpa Tangga", Rifka Media, No 53Mei-Juli 2013, Yogyakarta.

Talbot, Christine, 2011, “The Church Family in Nineteenth-Century America: Mormonism and the Public/Private Divide", In Journal of Mormon History, Vol. 37, No. 4 2011, pp. 208-257 tersedia secara online dalam http://www.jstor.org/stable/23292608Accessed: 21-04-2016 


\section{3:00 UTC.}

Usman, Sunyoto, 2010, Pembangunan dan Pemberdayaan Masyarakat, Pustaka Pelajar Yogyakarta.

Yuliani, Sri, 2011, "Negara dan Tubuh Perempua: Menguak Kontruksi Patriarkhis Dalam Kebijakan Pulik Tentang Prostitusi dan Pornografi” dalam Rangkaian Bunga Rampai Pergeseran Paradigma Pembangunan Pemberdayaan Perempuan Menuju Pengarusutamaan Gender, Cakrabook, Solo.

Sumber Lain:

Anonim, Potret Gender Tahun 2016, Kementerian Pemberdayaan Perempuan dan Anak, 2017, Jakarta

Dinas Tenaga Kerja Kabupaten Purbalingga, Laporan Tahunan Ketenagakerjaan tahun 2016 tidak diterbitkan.

Harian Radar Banyumas, Kamis 17 November 2016 Kasus Kejahatan Seksual di Purbalingga Tinggi Sumber: https://radarbanyumas. co.id/kasus-kejahatan-seksual-di-purbalingga-tinggi/ Copyright (c) Radarbanyumas.co.id

Rencana Pembangunan Jangka Menengah Daerah Kabupaten Purbalingga, Tahun 2016-2021

Sakernas, 2013, Pembanguan Manusia Berbasis Gender Tahun 2013, Kementerian Pemberdayaan Perempuan dan Perlindungan Anak, CV. Lintas Khatulistiwa, Jakarta. 